\title{
Institutional embeddedness of mumpreneurship in the UK: A career narrative approach
}

\author{
Shandana Sheikh and Shumaila Yousafzai \\ Cardiff Business School, Cardiff University, UK.
}

\section{Presented in the 2015 International Diana Conference on Women's Entrepreneurship Research}

\begin{abstract}
The recent rise in the number of mothers who have started a business from home along with an increase in publicly available profiles of these women has led to the trend of mumpreneurship, i.e., women who set up and manage a business around their child caring role. This research employs a career narrative approach to examine the stories told by a group of 12 British mumpreneurs within the context of UK's regulatory institutions. The findings suggest that despite having dual responsibility of motherhood and business ownership, mumpreneurs work hard to achieve their aspirations and career objectives. However, their ability to do so is severely constrained by the institutional support, more specifically in terms of child-care provisions and training and financial support.
\end{abstract}

\section{Introduction}

There is an increasing recognition that female entrepreneurs are the new engines for inclusive and sustainable economic growth (GEM, 2012). A variety of stakeholders have indicated that they are the 'rising stars of the economies' (Vossenberg, 2013), the 'untapped source of economic growth and development' (Minniti and Naudé, 2010), 'the way forward' (World Economic Forum, 2012), and the 'new women's movement' (Forbes, 2011). In an effort to achieve higher levels of economic and regional growth, the UK government aims to reduce the entrepreneurial gender gap along with the objective of encouraging more mothers to enter into entrepreneurship (Harding, 2007; Women Enterprise Task Force, 2009). However, despite of being an important contributor to UK's economic growth and development, women's entrepreneurship (WE) rates fail to keep up with the government's target. This research aims to study a subset of WE, i.e., 'mumpreneurs' referring to 'an individual who discovers and exploits new opportunities within a social and geographical context that seeks to integrate the demands of motherhood and business ownership' (Ekinsmyth, 2011: p. 105).

In the UK, there are around 1.2 million self-employed women of which approximately 300,000 are mumpreneurs, contributing 7.4bn to the UK economy each year (Start Up Donut, 2014). Several push and pull factors (e.g., soaring childcare costs, glass ceiling, inflexible nature of employment, desire for independence and autonomy and a desire to achieve a better work-family balance) have led mumpreneurship to become a common pathway for a number of British mothers (Grady and McCarthy, 2008; Mallon and Cohen, 2001; Patterson and Mavin, 2009; Rouse and Kitching, 2006). A recent survey suggests that $65 \%$ of British mothers, with children under the age of 10 years, consider starting a business from home in the next three years (Direct line Survey, 2014). However, the desire of attaining a balance between self-employment and family is a complex one (Shelton, 2006) and the extent 
to which women are able to cope with this challenge partly depends on the institutional support available to them.

Institutions can constrain or enable individuals in their behavior and action by setting boundaries that influence the extent of entrepreneurship and its development (Welter and Smallbone, 2011). Regulatory institutions such as government's family policies regarding social welfare, education and tax, can directly or indirectly affect the rate and nature of WE activity (Hegewisch and Gornick, 2011). Furthermore, these institutions affect the perceptions of women in a society and thus determine the extent to which women can actively participate in the labour market (Sjoberg, 2004). For example, in countries where extensive and affordable child day care provisions are made by the state, women may face less trade-off between career and family responsibilities and hence may become more active in the labor market and selfemployment (Kreide, 2003).

This study employs a career narrative approach to examine the stories told by a group of 12 mumpreneurs within the context of UK's regulatory institutional context, specifically the family policies framework. In the UK, while there are current family policies such as childcare benefits, tax credits, maternity leaves and parental allowances, the impact of these policies on mumpreneurship has not been studied. Our objective is to explore how mumpreneurs construct their experiences of moving into entrepreneurship and how regulatory family policies support or constrain them in simultaneously balancing their dual responsibility of business ownership and motherhood. This study will potentially contribute to the existing small number of studies on mumpreneurship by informing policy makers to revise the strategies targeted towards mumpreneurs including state provision of childcare facilities, which is a major factor in supporting or constraining mumpreneurship. This study may also potentially inform future mothers who juggle between motherhood and paid employment and face constraints in balancing this dual responsibility. It could encourage more women to become mumpreneurs, thus contributing to the growth of British economy.

We begin by discussing the institutional embeddedness of mumpreneurship our research design and methodology. We then move on to analyse our findings based on the narrative accounts of mumpreneurs, in an effort to get an in-depth understanding of the institutional challenges mumpreneurs face in achieving workfamily balance. Our discussion focuses upon identifying perceived gaps in institutional support that affect mumpreneur's work-family balance.

\section{Institutional embeddedness of mumpreneurship}

The transition to motherhood in most women's life changes their choices, priorities and career preferences (Ekinsmyth, 2013). The concept of mumpreneurship is often associated with the objective of simultaneously being a good mother and a good business owner. In researching this unique form of entrepreneurship the boundaries between work, motherhood and home are made flexible and permeable. To demarcate the difference between mumpreneurship and other businesses in the capitalist societies, one needs to look beyond the work place and focus more on work that originates within the household and community places, both of which help to construct the mumpreneurship label (Oberhauser, 2000).

Although, the number of working mothers in the UK has increased to 5.3 million since 1996, (The Telegraph, 2013) there is consistent evidence that women 
has paid the price of becoming mother by not only losing out on financial independence and career progression but also face considerable role-conflict and strain, termed as the 'motherhood penalty' (Amelia, 2009; Daly, 2011). Critiquing the phenomenon of adaptive preferences in Hakim's (2000) preference theory, Leahy and Doughney (2006) explain that it is not a personal preference that women adapt their work and family roles. Instead, such adaptation are made with little choice and are mostly a result of the structural realities of family life as well as the societal attitudes and pressures on a woman.

The institutional support, in terms of family welfare policies that reconcile a woman's work and family obligations, have the potential in various degrees to reconcile the tension between work and family obligations (Sjoberg, 2004). Although, measures for better work-life reconciliation and gender equality, for example, maternity leave and the provision of childcare have become a major policy issue on the European social agenda (Ciccia and Verloo, 2012; Fagnani, 2011), policy makers in the UK have largely ignored the link between family and work. In the marketoriented model of UK, which puts most of the care responsibilities with families with little state support (Korpi et al., 2013), working mothers face greater work-family conflict. Compared to this, the pro-family model of Scandinavian countries encourages greater participation of women in the workforce, frees women time to pursue their professional development and also reduces work-family conflict (Gornick et al., 1997; Petit and Hook, 2005).

Since the late 1990's, the Labour government took major reforms of employment and social policies with the aim of assisting families with children, for example, increasing incentives for women to work, including longer maternity leaves and subsidized provision for childcare (Harkness and Evans, 2011). However, despite significant improvement, a gap still remains within the UK's family welfare policies to reconcile family and work. For instance, with an increase of $10 \%$ each year, the childcare costs in the UK are the highest as compared to other OECD countries (Daycare Trust, 2013). According to recent estimates British parents with two children could pay as much as $12000 £$ in a year (The Telegraph, 2014). The statefunded childcare provision for children less than 3 years is made for a few hours, implying that mothers resort to other private or in-formal arrangements or choose part-time working patterns (Ciccia and Bleijenbergh, 2014). The shift from the Labour Party to Coalition government in 2010 has made matters worse. Their deficit reduction plans, in terms of cutting down on welfare spending and public service provision, has resulted in a 'triple jeopardy' for women including cuts in public sector jobs, wages and pensions, state services and benefits (Annesley and Scheele, 2011). According to a recent survey of 300 working mothers, $24 \%$ had to stop work due to the recent cuts in child tax credit by $10 \%$ (Resolution Foundation, 2012).

There is a gap in WE literature in developing our understanding of how institutional policies and attitudes towards mumpreneurship are structured in the UK. In the next section we will employ a narrative approach to explore the role of family policy institutions in shaping the opportunity structure of mumpreneurs.

\section{Method}

The empirical data for this study were collected through phenomenological in-depth interviews conducted with 12 mumpreneurs. Although there are a few interpretive studies in entrepreneurship literature, much of the research is dominated by objectivist and positivistic gender-neutral approach to studying entrepreneurship. In line with 
feminist researchers' proposition for an epistemological shift towards a constructivist inquiry that utilizes more qualitative methods to study the various aspects of WE (Ahl, 2006; 2007; Bird and Brush, 2002; Foss et al., 2015), this study adopts a constructionist approach to understand the lived experiences of mumpreneurs. The aim was to uncover the experiences and challenges that mumpreneurs face in balancing the dual responsibility of motherhood and business ownership, in the presence of current government family policies.

A purposeful sampling strategy was adopted wherein participants were recruited through website search of various mumpreneur networks and groups, articles and mumpreneurship blogs. Table 1 provides a summary of the interviewees. All but 3 (unmarried single mothers) were either married or divorced and remarried and living with partners. The three single mothers were also the sole income earners for their family. All businesses were based online except for 3, which also had physical premises in addition to the online presence. None but one of the businesses employed people except the owner, reflecting the small-scale nature of mumpreneur businesses. In 3 cases, the husband helped in managing the business either in parttime capacity or because he had left his job and started working for his wife's business. All businesses were based in the UK, although some were involved in catering to a global customer base.

\section{---Insert Table 1 about here---}

\subsection{Data collection}

In-depth, open-ended interviews lasting between 45 minutes to an hour were conducted with 12 mumpreneurs. While fixed boundaries were not set, interviewees were asked to develop a personal narrative about their experience of being a mumpreneur and highlight the challenges that they perceived relevant and important with regards to achieving a balance in their dual role as a mother and a business owner in the wider context of government's family policies (Larty and Hamilton, 2011). There was little interruption in the conversation from the researcher except for a few prompts that were used to guide the interview. All interviews were audio recorded and transcribed verbatim, in an effort to address issues of credibility and accuracy of accounts (Lincoln and Guba, 1985).

\subsection{Data analysis}

The data from the interviews was analyzed in four steps. First the authors read and reread the transcripts to develop a holistic understanding of each mumpreneur's experiences. Next, following an idiographic analysis, each of the transcripts was coded into themes that could be identified with the data. These transcripts were then compared with each other using thematic analysis, to highlight similarities and differences between interviewees' accounts and also to highlight central issues related to the phenomena under study.

\section{Findings}

The findings of the study are presented in terms of four themes that were identified in the process of data analysis. These include: (i) the motivations and aspirations of mumpreneurs; (ii) the challenges involved in balancing the demands of being a mother and an entrepreneur; (iii) the role of childcare provisions in supporting or constraining mumpreneurship; and (iii) perceptions regarding government's support for women entrepreneurs. 


\subsection{From mum to mumpreneur: motivations and aspirations}

In line with previous research, the interviewees' narrative identified a combination of push and pull factors that motivated mumpreneurs for starting an enterprise (Duberley and Carrigan, 2010; Jayawarna et al., 2011). For example, for four of the mums (Zen, Samy, Taz and Lizy), the main reasons for starting an enterprise were flexibility, the opportunity to spend more time and to be available to look after their children, and the expensive cost of childcare.

\footnotetext{
'....because if you go back to work, you would just be paying your childcare and that's sort of ridiculous...that is one of the reasons I started because I wanted to be home with my kids, I didn't want to put them in childcare' (Samy)
}

Jenny and Pensy entered mumpreneurship because of their sheer desire of being their own boss and Dee and Tash launched their own enterprise because of their passion for what they wanted to do and the flexibility of being with their children. In addition to being passionate about what they wanted to do in life, Chloe, Sina, and Viks started an enterprise due to redundancy. Another pull factor was identification of a need for a product. For example, Emily started her business as a result of her illness:

'When my youngest daughter was 7 months, I was still breastfeeding her, I was diagnosed with breast cancer...led to the chain of treatments one of which was chemotherapy as a result of which I lost my hair. I felt I had to cover up all the time and all I really wanted was to have this need for a baby hat like my daughter was wearing.'

With respect to the future aspirations, each of the mumpreneurs except Emily, (who wanted her business to remain small so that she could manage it around her daughters) aspired to expand their business, increase growth opportunities and sales and hire more people to be able to manage the increased growth of their enterprise. They agreed that such aspirations would need government's support in terms of training and funding. Some mumpreneurs whose businesses were stable (Dee, Sina, Zen and Chloe) did not express much need for funding as others who were still in the introductory stage. For instance, Dee was of the opinion that the government should not be looked upon for support. For her, it was self-motivation and individual effort that determined the success of her business.

Based on Jayawarna et al.'s (2011) typology, five mumpreneurs (Emily, Samy, Viks, Tash and Taz) could be termed as convenience mumpreneurs as they had the objective to increase sales and hire more staff to grow their enterprise, but expressed their main priority as their children and the desire to manage their business around their children routine. Four mumpreneurs (Chloe, Jenny, Pensy, and Dee) could be classified as learning and earning mumpreneurs due to their aim of expanding their businesses, increasing product lines, becoming bigger and even franchising. While children still being their main priority, they strived to move up on their learning curve and also to take their business up to a level that they could foresee. Finally, in addition to being a learning and earning mumpreneurs, Lizy, Sina and Zen could also be termed as a social mumpreneurs. They provided mentorship for other mothers who were thinking of starting a business or just started one. As Sina expressed her future aspirations to be:

'I want to make a statement online so that I am able to help as many people as I can. I coach to different parents to in my lectures that we are extremely lucky that we can do two things at a time. Women are multi-taskers, we don't have to make choices between being a parent and being a business owner. Its hard but it is not impossible.

\subsection{Juggling balls between childcare and business responsibilities}

The narrative identified the task of maintaining a balance between motherhood, business, and housework as a major constraint that all mumpreneurs were facing. Although, they took pride in how they managed to fit their work around their 
children's routine, the mumpreneurs termed the task as a 'constant juggling act where if one ball drops the whole lot would drop' (Viks). As Emily described:

\footnotetext{
'I try and give as much time to both...the girls are in school from 9am to 5pm so I am back at my desk at 9 o'clock and I work through until $3: 15 \mathrm{pm}$ after which I go to the post office to deliver the orders and then go pick the girls....and then depending on what we are doing, I can still answer a few emails on my phone, I can do a few bits... once they have gone to bed, I work at least an hour or two on jobs that I don't really need to think about the next day.' (Emily)
}

Although, a few women were lucky to have help from their husbands or family (Chloe, Zen, Dee and Taz) most of them had the major share of responsibilities related to housework and childcare. For example Chloe, Taz, and Viks narrated:

\footnotetext{
'My husband is very lucky because he works for a company that lets him do flexible hours. He works in the beginning of the week. So Mondays, Tuesdays and Wednesdays, I would do the school runs and everything and then Thursdays, Fridays and Saturdays, he would look after the
children so that I can work longer hours.'(Chloe)

'...basically we have an arrangement with another family who live opposite to us...their dad is also self-employed. So on Mondays their daughter comes with us after school so he could work for longer hours and then the next week my daughter goes to their house after school so that I can work for longer hours, so I can get full day of work till 6pm, if I need to go for work, go out or something like that.' (Taz)

'I actually don't think I could have gotten to the level I am at if mum hadn't been able to help, because he (her son) can occupy himself to an extent but he has special needs of autism. He is still in nappies so with that you have to constantly leave what you are doing to change a nappy and things like that... so I couldn't have done that with the business. I was happy that mum retired and took over.' (Viks)
}

While these mumpreneurs tried to balance childcare, business and housework, they did experience lack of time for their own self. Thus, where self-employment gave them the flexibility to work around their children, it also reduced the time that they could have for themselves as they did when they were in paid employment. For example, Viks narrated:

\footnotetext{
'The business gets time and the kids get time but the biggest thing for me is that I don't get time for myself. I don'twatch films and even when I do its on my laptop or iPad while washing and it takes two weeks to watch a film...things like that, I kind of miss... while before when kids were in bed at 7 or 8 o'clock that was me free to watch a film or play the computer...that is the hardest thing for me and some days it doesn't bother me but some days it does.'(Viks)
}

\subsection{The critical role of the quality and cost of childcare provisions}

Overall there was a general perception among all mumpreneurs, regarding lack of government support for providing good quality and low cost childcare. It was believed that the provision for free childcare was not sufficient, especially for children below school age. This led to the high expenditure on private childcare, which was unaffordable and thus pushed them towards working for longer hours to cover the costs. For all of the mumpreneurs (except Sina, Jenny and Lizy), childcare provisions were made by private rather than the state nurseries primarily due to the longer opening hours of private nurseries (Dee) or because they perceived private nurseries to be better than the state nurseries in terms of the attitude towards learning, the behaviour and quality of staff, staff to children ratio, better facilities and better learning and development (Dee and Zen). Even where some mumpreneurs (Taz and Zen) could get a free entitlement in a state nursery, the timings did not match their working hours and thus they sent their children to a private nursery.

\footnotetext{
‘...she is due for free entitlement to the government nursery but I will probably just continue with the private one...... the government one is 2.5 hours per day and by the time I drop her, get an hour of work done, its time to go back...its absolutely impractical unless you are a stay at home mum, it doesn'twork for you.' (Zen)
}

In the special context of Viks with two children with special needs (one autistic and the other dyslexic), she felt that there was no provision in local school for one to one support for her children. Viks home schooled her children and did housework during the day and worked during the night. She highlighted the limited resources and funding from the government as a major constraint to the quality of teaching and learning in state funded primary schools. Although, Viks was in receipt of the Disability Living Allowance (DLA) for her children she felt that the application process was a pain. Further, she expressed her dissatisfaction with respect to the 
caretaker, which she was not entitled to, despite the fact that both her children had special needs. She explained:

\begin{abstract}
... the private one couldn't detect or identify the issue with Jay... whereas the local one saw that there was an issue......unless the government gives teachers the resources they need, you are stuck. Jay's teacher made a lot of effort to find extra resources for Jay....but she wasn't getting any extra credit for doing that from the education board. I get the DLA for Jay but then there are 30 page interrogation forms for that and then what he gets as a child is the same as adults who are on drugs and for them there are no questions. I asked if I could get a disability nurse or a social worker, but we are not entitled to it coz Zee's (son) IQ is more than $70 .$. he is not classed as having a learning disability... I am not doubting my worker, but we are not entitled to it coz Zee's (son) IQ is more than 70....he is not classed as having a learning disability... I am not doubting my son's intelligence but there are other issues... sometimes I have to change 27 nappies in one day, he has major bowel issues, but no consideration given to his physical needs...if he is going to go out of the class and gets his nappy changed frequently, he will not learn as much as the other kids, he is going to be at a disadvantage.' (Viks)
\end{abstract}

Moreover, some mumpreneurs (Chloe, Zen, Tash and Viks) perceived that due to the soaring childcare costs working mothers were worse off and were discouraged to work while the stay-at-home mothers could still take advantage of all the benefits. They criticised the Government's policy of free childcare to every mother regardless of their working status:

\footnotetext{
‘. while I was working and doing my job, there were all those mums who were not working but they were taking their kids into free childcare and because their kids are in nursery, they can go off to the gym....that's a problem when you give free child care to everybody, people who don't necessarily need it occupy the spaces and those who do need it don't get any.' (Chloe)

'...may be that's the trick of the government, to have mums be at home and care for children...this may be a good thing but not for someone like me who wanted to work and didn't want to take a 3 year break from work.' (Zen)
}

All mumpreneurs agreed that more specific support was needed for small business owners in terms of childcare especially during the school holidays. This was considered to be a challenge for most mumpreneurs as it restricted the amount of work they could do while their children were at home. Dee narrated:

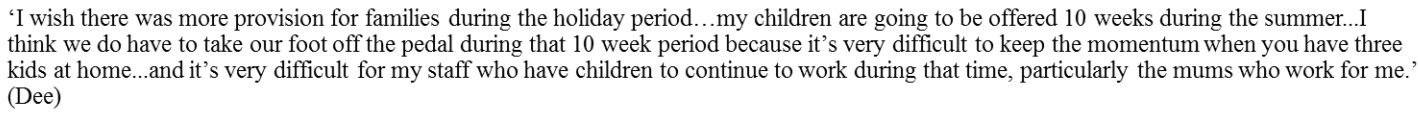

While, all of the mumpreneurs perceived the costs of childcare to be unaffordable, there was general appreciation of the child tax credit (CTC: 70\% of the childcare costs) and child benefit that was provided by the government. Although, most felt that it was not enough compared to the cost of childcare. Eight mumpreneurs were receiving CTC, while four were not eligible due to higher earnings levels. Emily expressed her appreciation of CTC as:

\footnotetext{
'...had it not been for tax credits, I wouldn't have been in business... when I got divorced, the girls would have been severely disadvantaged...I would have got at least part-time job, probably a full-time job really...the girls wouldn't be able to go to brownies, no swimming lessons, no piano.... I am very grateful for that opportunity to have tax credit.' (Emily)
}

The mums also highlighted important drawback in the CTC system in which the calculation of income to determine CTC was done by taking into account incomes of both partners and that the calculation of CTC was based on the previous year income instead of real time income. As Samy and Zen explained:

\footnotetext{
me and my partner have two children from our previous marriage so our money isn't joint... when you have something like CTC, our money goes on it as joint but we don'tessentially share our money so we don't get tax credit. I am earning and he is earning but we have two other children.' (Samy)

'...its a shame, we feel it because we have three children and that is 299 pounds per week...that was for my children, their extra curricular, swimming lessons and all used to be funded by that money.' (Zen)
}

\title{
4.4. Perceptions regarding Government's support for women entrepreneurs
}

Most mumpreneurs perceived a lack of governmental support for women entrepreneurs in terms of training courses that can help them to develop and learn marketing, accounting, finance, PR and social media skills that are critical to run an effective and efficient business and also in getting funding for future growth. Zen and Sina, who acted as mentors for potential female entrepreneurs, explained how lack of knowledge and training for entrepreneurship makes most mothers struggle in their 
businesses. Zen who gets specialized help for her business acknowledged the constraint faced by other mumpreneurs who are not able to do so by explaining that, 'you are the jack of all trades, something goes wrong, you have to fix it, there is no IT department.' Viks narrated:

'I had to teach myself proper photography, taking photos with shadows and stuff like that...I have resorted to using Google...I had a camera that I used but had to figure out the buttons...so again YouTube! Yes, a lot of things I had to learn and teach myself...if I were to go to professionals,

there would be no profit left.' (Viks)

Other mumpreneurs relied on family (Samy), or other self-employed people (Zen, Jenny, Pensy) who were then paid for their services. Few mumpreneurs who did get the training and attended free courses felt that it was not enough. As Dee explains:

\footnotetext{
..'It's a little bit of training...if you are really committed to make a serious difference to your business, it isn't enough and as I said that the learning curve is very steep...it's nice to have this training but it's not game changing.' (Dee)
}

Most mumpreneurs also perceived that there was lack of funding and grants for women entrepreneurs. This was mainly attributed to the perception of mumpreneurship as a hobby instead of an actual 'serious business'. Others (Lizy) believed that the government does give out funding but the banks are not prepared to lend it out to mumpreneurs. Zen and Viks narrated their feelings:

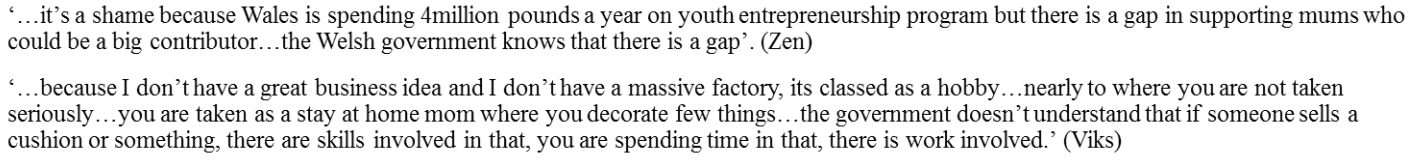

Sina, a coach for mumpreneurs, confirmed this perception but suggested:

\footnotetext{
'...you see because its safe area for mums to start a business doing what they love, so you know if someone is making cupcakes and cakes, it all starts as a hobby, of course you do want to test your water, you don't want to launch big and then end up failing... so mums start small, they see the water and see if people are generally interested and they are getting feedback and response...once the seed takes off, they start doing it.' (Sina)
}

Another area where some mumpreneurs felt that support would be appreciated was the allowance for sick leaves. As compared to paid employment where these women had an allowance of sick leaves or general leaves, self-employment did not offer any such benefits. Emily, who remains in and out of the hospital due to her illness expressed:

\footnotetext{
... 'I don'thave sick leaves and that's a major issue, being in and out of hospitals quite a lot... a couple of years ago, I had a major surgery, so what do you do? You still carry on and do every little that you can.' (Emily)
}

Further, Viks narrated her experience when she fell sick and it took her a month to recover. Being the only person responsible for making orders and dispatching them, she fell behind orders due to her being unwell. Moreover, she did not want her customers to know that she was sick, as she did not want to gain sympathies nor wanted to lose customers. She explained:

\footnotetext{
... 'what would take me half an hour was taking me one day and I felt the pressure. I tried to go to the office in my pajamas trying to complete the orders for the simple fact that I couldn't afford 4 weeks off'. (Viks)
}

All mumpreneurs generally believed that they could not just afford to take time off, since they couldn't afford to shut their business and lose out on customers as well as money. It was difficult for these women to take holidays and even when they did, they would be constantly working from their laptops or phone. Therefore, as agreed by all 'self-employment is not a 9-5 job but a job where you are working all the time'.

From an interpretation of the accounts of mumpreneurs, there was a general perception that the support available from the government is not well marketed and 
therefore does not help mumpreneurs. Mumpreneurs perceived that they help each other through the various networks and social media networks. However, there is little information about what is available from the government. As Viks explained:

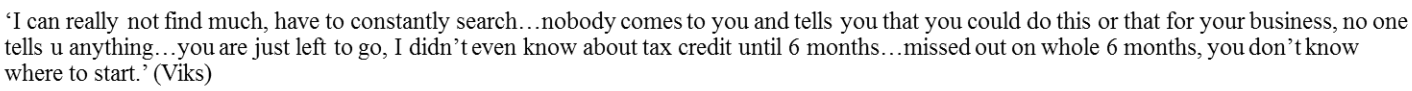

'I can really not find much, have to constantly search... nobody comes to you and tells you that you could do this or that for your business, no one tells $\mathrm{u}$ anything... you are just left to go, I didn't even know about tax credit until 6 months... missed out on whole 6 months, you don't know where to start.' (Viks)

While all the interviewees were UK based, a few had lived outside UK (Sina, Jenny and Emily) for a few years and thus expressed their positive opinions about the family pro policies that European countries offered for mumpreneurs and they believed that UK fell short of such initiatives. Lizy held the same belief that European countries had a much better stance in supporting a mumpreneur's juggle between being a good mother and a good business woman. She said that it had not worked well for UK as of now. For example, with regards to taking time off as in case of illness, Sina compared UK to Norway and explained that in latter, one could get a financial compensation based on the income. Further, with regards to maternity allowances, Emily mentioned Germany's 3-year maternity leave policy. Although the entire 3 year period was not paid but one did get the social security during this period and also the right to one's job at an equivalent level. Emily further expressed that Germany had a totally different mindset than the UK. She added:

\footnotetext{
...it's a different mindset in Germany... that whole attitude of family is so important and it has worked really well for Germany... in the UK if someone said I need 3 years off to have my child, the company would be quite annoyed about it. In Germany the whole mindset is that you need to be at home to look after your children when they are very young and there is no fear of losing your job whereas in this country there is a lot of pressure to go back to work as soon as possible.' (Emily)
}

In the light of mumpreneurs' narrative accounts, there was a consensus that more needs to be done in the UK for self-employed mothers. Although, mumpreneurs perceived self-employment as a flexible way to manage both work and family, they also felt that due to lack of available support from the Government, despite of working harder and longer hours they were facing a constant guilt of not being a good mother and a good business woman.

\section{Discussion}

While women owned businesses are increasing in number, the discourse of underperformance of women enterprises compared to their male counterparts still hold (Ahl, 2006; Marlow et al., 2008; Powell and Eddleston, 2008). However, this myth of underperformance has been criticized by feminist researchers, suggesting that it is not under performance but rather constrained performance of women entrepreneurs which differentiates them from male entrepreneurs (Marlow and McAdam, 2013). Therefore, to explain reasons for underperforming, one must look beyond just gender differences but rather pay attention to structural factors that affect women's entrepreneurial activity in a country.

Policy makers in the UK have largely ignored the link between family and work. UK's policy frameworks have worsened the work-family reconciliation instead of attempting to support it. The transition to motherhood in a woman's life is seen as a change in her preferences of employment versus business ownership (Ekinsmyth, 2013). A woman's caring role and family responsibilities are considered to be deeply associated with her leading to a trade-off between the caring role as a mother and the desire to be independent and follow one's career. Women use home based businesses as an optimum strategy to achieve work-life balance, which consequently limits their economic growth and success (Loscocco and Smith-Hunter, 2004). Analysis of mumpreneurs' narrative reveals that they are constrained in their daily lives by 
domestic responsibilities, which in turn determine the amount of time they can devote to their business.

Furthermore, only three out of twelve women indicated that they got help from their husbands in managing children, reflecting the gendered division of labour between paid and unpaid work where most of the responsibility of housework and family is on women (Jennings and McDougald, 2007). Even where women did get help from their husbands, they performed much of the domestic work. The distribution of paid and unpaid work is also affected by the role of institutions, which have implications for access to resources and business development (Welter, 2011).

Our findings suggest that most mumpreneurs have started a business from home in an effort to work around their children. While this fulfils the good motherhood expectation, which is socially constructed by social norms of the society, it affects the performance and growth opportunities of the businesses run by these women. All mumpreneurs expressed a deficiency in the provision of local childcare, a barrier that constrained them to work for their business. While CTC and child benefit schemes were acknowledged by mumpreneurs, it was considered to be insufficient to cover the costs of childcare. This is supported by recent evidence which suggests that two-thirds of parents who use formal care for their children pay for it while only $6 \%$ pay for informal care (Huskinson et al., 2013). Moreover, there were problems with access to free spaces in nurseries, timings of free provision which mismatched working hours and absence of childcare provision during school holidays. Even where local childcare was accessible, mumpreneurs were dissatisfied with the quality of childcare and the learning and development impact it had on their children. Recent statistics confirms this evidence suggesting that compared to other OECD countries, UK is considered to have the highest cost of childcare and lower care quality reflected in the staff-child ratio and staff qualifications levels (Penn and Llyod, 2013). These inefficiencies in government's family policies had implications for mumpreneurs who juggled between their roles of a good mother and a successful business owner.

The importance of social networks for women entrepreneurs has been highlighted in previous research (Manolova, et al 2007). Lack of formal childcare highlighted in the narratives of mumpreneurs, reveals the importance of social networks and family in achieving work-family balance of mumpreneurs. Our findings suggest that most mumpreneurs rely on their family members, friends or neighbours for childcare, for the reason that they could not afford the costs of private care. Moreover, for some mumpreneurs, formal childcare did not offer any benefits because of the special needs of their children. Moreover, owing to the small size of the businesses, most mumpreneurs rely on self-taught learning while some engage in an exchange of services with other women in business, through mumpreneur networks. The reliance on informal networks is an outcome of unavailability of support from the government for mumpreneurs.

Despite the significant contribution of home-based enterprises and specifically mumpreneurship to economic growth of UK, their importance has been undermined. There has been previous evidence suggesting that the invisibility of home-based businesses makes them get ignored by the government (Mason et al., 2011). Not only this, but most small businesses, those started from home are perceived as a hobby and thus not considered to be important. Nearly all mumpreneurs in this study agreed with this perception and attributed this to the negligible support they received from the government. This points towards the general discourse of disintegration of 
motherhood and entrepreneurship where two are not associated. In comparison to the entrepreneur, the social and cultural construction of motherhood is more trivial, which results in mother owned businesses being perceived as less serious and limited in performance and scope. Such trivialization of motherhood poses an enduring challenge to mother entrepreneurs who struggle to balance their roles of a good mother while being a good business owner. We believe that to visualize the growth of mumpreneurship, attention must be given to the context within which these businesses are embedded. The narrative accounts of mumpreneurs signify that women have multi-tasking abilities, are naturally talented and can have all walks of life. With the necessary support and resources, these women can contribute significantly to a happy family and prospering economy.

\section{Conclusion}

This small-scale exploratory study attempted to trace the institutional embeddedness of mumpreneurship. While the trend of mumpreneurship has been on the rise, there are challenges in managing such businesses. We aimed to highlight some of the challenges that mumpreneurs face in balancing their dual identities of being a good mother and a successful business owner, in the light of government's family policies. While the UK government is making a number of efforts to support families, women and children, the outcomes of these efforts have not been evaluated. Our research suggests that the major reason for starting a business for mothers is to spend more time with their children and to manage work around their caring role. However, this does not suggest that mumpreneurs spend less time in work and have low ambitions for themselves. Out research suggests that despite having dual responsibilities, mumpreneurs work hard to achieve their aspirations and career objectives. However, their ability to do so is severely constrained by the institutional support, more specifically in term of child-care provisions and training and financial support. Mumpreneurs perceived that the small-scale nature of their business makes it invisible and unimportant for government support and there was a general consensus that mumpreneurship is under recognized by the government and hence call for more support for these businesses.

\section{Limitations and future research}

This study aimed to highlight the challenges of mumpreneur businesses in the light of government family policies. Although we believe that this study offers rich insights to the phenomena under study, it is limited in its scale. Due to the nature of qualitative approach that we followed, the findings of the study are not representative of all mumpreneur businesses. Although, the use of phenomenological interviews helped to uncover the experiences of mumpreneurs and challenges they faced in current time period. These experiences may change due to individual circumstances. For example, when children start attending school, mumpreneurs may be able to put in longer hours in their business and could develop their business successfully. Moreover, certain policies may become irrelevant to mumpreneur's work-family balance while some other may be more relevant in future, depending upon the nature of business activity and life stage (Jayawarna et al., 2011). We also suggest a comparative study of mumpreneurs with women without caring responsibilities in order to highlight the differences in performance outcomes as well as challenges between these groups of women. Finally, one could also compare family policies and their effect on mumpreneurs in UK and Scandinavian countries, which follow a pro family model. This would help to build a model for the future of family policy for the UK. 


\section{Bibliography}

1. Ahl, H. (2006). Why research on women entrepreneurs needs new directions. Entrepreneurship Theory \& Practice. Volume 30(5), pp. 595-621.

2. Annesley, C. and Scheele, A. (2011). Gender, capitalism and economic crisis: impact and responses. Journal of Contemporary European Studies. Volume 19(3), pp. 334-348.

3. Bird, B., and Brush, C. (2002). A gendered perspective on organizational creation. Entrepreneurship Theory and Practice. Volume 26(3), pp. 41-65.

4. Ciccia, R., \& Verloo, M. (2012). Parental leave regulations and the persistence of the male breadwinner model: Using fuzzy set ideal type analysis to assess gender equality in an enlarged Europe. Journal of European Social Policy. Volume 22(5), pp. 507-528.

5. Ciccia,R. and Bleijenbergh,I. (2014). After the Male Breadwinner Model? Childcare Services and the Division of Labor in European Countries. Social Politics. Volume 21(1), pp. 50-79.

6. Daly,M. (2011). What Adult Worker Model? A Critical Look at Recent Social Policy Reform in Europe from a Gender and Family Perspective. Social Politics. Volume 18(1), pp. 1-23.

7. Direct Line Group, (2014). The Rise of the Mumpreneur: Two thirds of mums consider launching a business from home. Online. URL http://www.directlinegroup.com/media/news/brand/2014/03-04-2014.aspx. Accessed on 13-03-15

8. Duberley,J. and Carrigan,M. (2012). The career identities of 'mumpreneurs':Women's experiences of combining enterprise and motherhood. International Small Business Journal. Volume0(0), pp. 1-23.

9. Eddleston,K.A. and Powell,G.N. (2008). The role of gender identity in explaining sex differences in business owners' career satisfier preferences. Journal of Business Venturing. Volume 23(2), pp. 244-256.

10. Ekinsmyth, C. (2011). Challenging the boundaries of entrepreneurship: the spatialities and practices of UK 'mumpreneurs'. Geoforum, Volume 42(1), pp. 104-114.

11. Ekinsmyth, C. (2013). Managing the business of everyday life: the roles of space and place in "mumpreneurship". International Journal of Entrepreneurial Behavior \& Research. Volume 19(5), pp. 525-546

12. Fagnani, J. (2011). Work-family life balance: future trends and challenges. Online. URL. https://hal.archives-ouvertes.fr/halshs00663849/document. Accessed on 12-04-15

13. Family and Childcare Trust (2013). Childcare costs survey. Online. URL http://www.fct.bigmallet.co.uk/sites/default/files/files/Childcare_Costs_Survey_FCT_2013_FINAL.pdf. Accessed on 12--4-15 
14. Forbes, (2011). Entrepreneurship is the New Women's Movement. Online. URL http://www.forbes.com/sites/work-inprogress/2012/06/08/entrepreneurship-is-the-new-womens-movement/. Accessed on 03-02-15

15. Gentleman, Amelia. (2009). Motherhood 'devastates' women's pay, research finds, The Guardian. Online. URL http://www.guardian.co.uk/lifeandstyle/2009/jul/10/mothers-wages-fawcett-society .

16. Global Entrepreneurship Monitor (2012). Global Report. Online. URL http://www.gemconsortium.org/docs/download/2645. Accessed on 10.03 .15

17. Gornick, J. C., Meyers, M. K., \& Ross, K. E. (1997). Supporting the Employment of Mothers: Policy Variation Across Fourteen Welfare States. Journal of European Social Policy, 7(1), 45-70.

18. Grady, G. and McCarthy, A. (2008). Work-life integration: Experiences of mid-career working mothers. Journal of Managerial Psychology. Volume 23(5), pp.599-622.

19. Hakim, C. (2000). Work-Lifestyle Choices in the Twenty-First Century: Preference Theory. Routledge, London.

20. Harding, R. (2007) State of Women Enterprise in the UK. Prowess: Norwich.

21. Harkness, S. and Evans, M. (2011). The employment effects of recession on couples in the UK: women's and household employment prospects and partners' job loss. Journal of Social Policy. Volume 40(4), pp. 675-693.

22. Hegewisch,A. and Gornick,J.C. (2011). The impact of work-family policies on women's employment: a review of research from OECD countries. Community, Work and Family. Volume 14(2), pp.119-138.

23. Henry,C.; Foss,L. and Ahl,H. (2015). Gender and Entrepreneurship Research: A review of methodological approaches. Online. URL http://munin.uit.no/bitstream/handle/10037/6753/article.pdf?sequence=1\&isAllowed=y. Accessed on 03-03-15

24. Huskinson, T., J. Pye, K. Medien, S. Dobie, C. Ferguson and C. Gardner, with N. Gilby, M. Littlewood and J. D’Souza (2013) Childcare and Early Years Survey of Parents 2011, SFR08/2013. London: Department for Education

25. Jayawarna, D.; Rouse, J. and Kitching, J. (2011). Entrepreneur motivations and life course. International Small Business Journal. Volume 29(1), pp. 1-23

26. Jennings, J.E. and McDougald, M.S. (2007). Work-family interface experiences and coping strategies: implications for entrepreneurship research and practice. Academy of Management Review. Volume 32(3), pp. 747-60.

27. Korpi, F.; Ferrarini,T. and Englund,S. (2013). Women's Opportunities under Different Family Policy Constellations: Gender, Class, and Inequality Tradeoffs in Western Countries Re-examined. Social politics. Volume 20(1), pp. 1-40.

28. Kreide, R. (2003). Self-employment of women and welfare-state policies. International Review of Sociology. Volume 13(1), pp. 205-218. 
29. Larty, J. and Hamilton, E. (2011). Structural approaches to narrative analysis in entrepreneurial research: Exemplars from two researchers. International Small Business Journal. Volume 29(3), pp. 220-237.

30. Leahy, M. and Doughney, J. (2006). Women, work and preference formation: a critique of Catherine Hakim's preference theory. Journal of Business Systems, Governance and Ethics. Volume 1(1), pp. 37-48.

31. Lincoln,Y.S. and Guba, E.G. (1985). Naturalistic Inquiry. Beverly Hills. CA: Sage.

32. Loscocco, K., and Smith-Hunter, A. (2004). Women home-based business owners: Insights from comparative analyses. Women in Management Review. Volume 19(3), pp. 164-173.

33. Manolova, T., Carter, N., Manev, I. and Gyoshev, B. (2007). The differential effect of men and women entrepreneurs' human capital and networking on growth expectancies in Bulgaria. Entrepreneurship Theory and Practice. Volume 31(3), pp. 407-426.

34. Marlow, S., Shaw, E. and Carter, S. (2008) Constructing female entrepreneurship policy in the UK: is the USA a relevant role model? Environmental Planning C. Volume 26(1), pp. 335-51.

35. Marlow,S. and McAdam, M. (2013). Gender and entrepreneurship. International Journal of Entrepreneurial Behavior \& Research. Volume 19 (1), pp $114-124$

36. Mason, C.M.; Carter,S. and Tagg,S. (2011) Invisible Businesses: The Characteristics of Home- based Businesses in the United Kingdom. Regional Studies. Volume 45(5), pp. 625-639

37. Minniti, M. and Naudé, W.A. (2010) What Do We Know About The Patterns and Determinants of Female Entrepreneurship Across Countries? European Journal of Development Research. Volume 22, pp. 277-293.

38. Oberhauser, A. (2002). Relocating gender and rural economic strategies. Environment and Planning A. Volume 34(7), pp. 1221-1237

39. Patterson, N. and Mavin, S. (2009) Women entrepreneurs: Jumping the corporate ship and gaining new wings. International Small Business Journal. Volume 27(2), pp.173-192.

40. Penn, H. and E. Lloyd (2013) The Costs of Childcare. CWRC Working Paper No. 18. London: Childhood Wellbeing Research Centre, Institute of Education.

41. Petit, B., \& Hook, J. (2005). The structure of women's employment in comparative perspective. Social Forces, 84(2), 779-801.

42. Resolution Foundation and Netmums. (2011). Childcare Tax Credit Survey. Online. URL http://www.resolutionfoundation.org/media/press-releases/childcare-tax-credit-survey/. Accessed on 14-04-15 
43. Rouse, J. and Kitching, J. (2006). Do enterprise programmes leave women holding the baby? Environment and Planning C: Government and Policy. Volume 24(1), pp. 15-19.

44. Shelton, L. (2006). Women entrepreneurs, work-family conflict and venture performance: New insights into the work family interface. Journal of Small Business Management. Volume 44(2), pp. 285-297.

45. Sjöberg, O. (2004). The role of family policy institutions in explaining gender-role attitudes: A comparative multilevel analysis of thirteen industrialized countries. Journal of European Social Policy. Volume 14(2), pp. 107-123.

46. Start Up Donut, (2014). Why does the number of female entrepreneurs continue to rise? Online. URL http://www.startupdonut.co.uk/blog/2014/03/why-does-number-female-entrepreneurs-continue-rise-uk. Accessed on 10-03-15

47. The Telegraph, (2013). Working mothers rise by a fifth in a generation. Online. URL http://www.telegraph.co.uk/finance/economics/10333890/Working-mothers-rise-by-a-fifth-in-a-generation.html. Accessed on 02-04-15

48. The Telegraph, (2014). Rise of the 'mumpreneurs' as childcare costs hit £12,000. Online. URL http://www.telegraph.co.uk/finance/personalfinance/10772101/Rise-of-the-mumpreneurs-as-childcare-costs-hit-12000.html. Accessed on $12-04-15$

49. Vossenberg, S. (2013). Women Entrepreneurship Promotion in Developing Countries: What explains the gender gap in entrepreneurship and how to close it? Maastricht School of Management Working Paper Series, pp. 1-27.

50. Welter, F. (2011). Contextualizing Entrepreneurship - Conceptual Challenges and Ways Forward. Entrepreneurship theory and Practice. Volume 35(1), pp.165-184

51. Welter, F., and Smallbone, D. (2011). Institutional perspectives on entrepreneurial behavior in challenging environments. Journal of Small Business Management. Volume 49(1), pp. 107-125.

52. Women's Enterprise Task Force (2009). Greater Returns on Women's Enterprise: The UK Women's Enterprise Task Force's Final Report and Recommendations. Department of Business, Innovation \& Skills. London.

53. World Economic Forum, (2012). Women as the Way Forward. Annual meeting. Online. URL http://www.weforum.org/videos/womenway-forward-annual-meeting-2012. Accessed on 10-03-15 


\begin{tabular}{|c|c|c|c|c|c|c|c|c|c|c|c|}
\hline Interviewee & Business & $\begin{array}{l}\text { Children's } \\
\text { Age }\end{array}$ & $\begin{array}{l}\text { Marital } \\
\text { Status }\end{array}$ & $\begin{array}{l}\text { Previous } \\
\text { Work } \\
\text { status }\end{array}$ & $\begin{array}{l}\text { No. of } \\
\text { employed } \\
\text { staff* }\end{array}$ & $\begin{array}{l}\text { Home } \\
\text { based }\end{array}$ & $\begin{array}{l}\text { Reasons } \\
\text { for } \\
\text { being } \\
\text { home- } \\
\text { based }\end{array}$ & $\begin{array}{l}\text { Years } \\
\text { in } \\
\text { business }\end{array}$ & $\begin{array}{l}\text { Sole } \\
\text { household } \\
\text { income } \\
\text { from } \\
\text { business? }\end{array}$ & $\begin{array}{l}\text { Jayawarna } \\
\text { et al.'s } \\
\text { (2011) } \\
\text { Typology }\end{array}$ & $\begin{array}{l}\text { Reason(s) for } \\
\text { becoming a } \\
\text { mumpreneur }\end{array}$ \\
\hline 1.Zen & Café & 2,6 and 9 & M & P.E & 6 & $\mathrm{~N}$ & - & 4 & $\mathrm{~N}$ & $\begin{array}{l}\text { Social, } \\
\text { L\&E }\end{array}$ & $\begin{array}{l}\text { Daughter's } \\
\text { birth, } \\
\text { difficulty of } \\
\text { managing } \\
\text { work and } \\
\text { children }\end{array}$ \\
\hline 2.Viks & Children toys & 5 and 10 & $\begin{array}{l}\mathrm{D} \text { and } \\
\mathrm{R}\end{array}$ & P.E & 1 & $\mathrm{Y}$ & $\mathrm{C} / \mathrm{F} / \mathrm{I}$ & 3 & $\mathrm{~N}$ & Conv Ent & $\begin{array}{l}\text { Redundancy; } \\
\text { to be there for } \\
\text { children } \\
\text { (special } \\
\text { needs) }\end{array}$ \\
\hline 3.Samy & Organic baby products & 3 & M & P.E & 1 & $\mathrm{Y}$ & $\mathrm{C} / \mathrm{F}$ & 1 & $\mathrm{~N}$ & Conv Ent & $\begin{array}{l}\text { To be there } \\
\text { for children }\end{array}$ \\
\hline 4.Taz & Events & 5 & M & P.E & 1 & $\mathrm{Y}$ & $\mathrm{C} / \mathrm{F}$ & 3 & $\mathrm{~N}$ & Conv Ent & $\begin{array}{l}\text { Daughter's } \\
\text { birth, } \\
\text { Flexibility of } \\
\text { working }\end{array}$ \\
\hline 5.Chloe & Organic food & 4 and 6 & M & P.E & 1 & $\mathrm{~N}$ & - & 10 & $\mathrm{~N}$ & L\&E & $\begin{array}{l}\text { Redundancy, } \\
\text { Passion for } \\
\text { cooking, } \\
\text { flexibility }\end{array}$ \\
\hline 6.Emily & Hair products & 8 and 11 & $\mathrm{~S}$ & P.E & 1 & $\mathrm{Y}$ & $\mathrm{C} / \mathrm{F}$ & 5 & $\mathrm{Y}$ & Conv Ent & $\begin{array}{l}\text { Need based } \\
\text { product, to be } \\
\text { there for } \\
\text { children }\end{array}$ \\
\hline 7.Lizy & Bedding products & 6 & $S$ & P.E & 1 & $\mathrm{Y}$ & $\mathrm{C} / \mathrm{F}$ & 5 & $\mathrm{Y}$ & $\begin{array}{l}\text { Social, } \\
\text { L\&E }\end{array}$ & $\begin{array}{l}\text { To be there } \\
\text { for Children }\end{array}$ \\
\hline 8.Tash & Design service & 2 and 6 & M & P.E & 1 & $\mathrm{Y}$ & $\mathrm{C} / \mathrm{F} / \mathrm{I}$ & 1 & $\mathrm{~N}$ & Conv Ent & $\begin{array}{l}\text { Passion; } \\
\text { Flexibility of } \\
\text { managing }\end{array}$ \\
\hline
\end{tabular}




\begin{tabular}{|c|c|c|c|c|c|c|c|c|c|c|c|}
\hline & & & & & & & & & & & $\begin{array}{l}\text { work and } \\
\text { children }\end{array}$ \\
\hline 9.Sina & $\begin{array}{l}\text { Multiple (interior } \\
\text { designing/cooking/mentoring) }\end{array}$ & 10 & $\mathrm{~S}$ & P.E & 1 & $\mathrm{Y}$ & $\mathrm{C} / \mathrm{F} / \mathrm{GR}$ & 5 & $\mathrm{Y}$ & Social,L\&E & $\begin{array}{l}\text { Passion; to be } \\
\text { there for her } \\
\text { daughter }\end{array}$ \\
\hline 10.Dee & Children products & $\begin{array}{l}5,11 \text { and } \\
12\end{array}$ & M & P.E & 10 & $\mathrm{~N}$ & - & 8 & $\mathrm{~N}$ & L\&E & $\begin{array}{l}\text { Flexibility of } \\
\text { working and } \\
\text { being there } \\
\text { for children }\end{array}$ \\
\hline 11.Jenny & Gifts & 19 & M & P.E & 1 & $\mathrm{Y}$ & $\mathrm{C} / \mathrm{F} / \mathrm{I}$ & 5 & $\mathrm{~N}$ & L\&E & $\begin{array}{l}\text { Disliking } \\
\text { working for } \\
\text { other people; } \\
\text { to be there for } \\
\text { children }\end{array}$ \\
\hline 12.Pensy & Gifts and greetings & 2 & M & P.E & 1 & $\mathrm{~N}$ & - & 2 & $\mathrm{~N}$ & L\&E & $\begin{array}{l}\text { To be there } \\
\text { for daughter } \\
\text { (special } \\
\text { needs) }\end{array}$ \\
\hline 13. Clay & Personalized bags and gifts & 5 & M & P.E & 0 & $\mathrm{Y}$ & $\mathrm{C} / \mathrm{F}$ & 3 & $\mathrm{Y}$ & L\&E & $\begin{array}{l}\text { Passion, } \\
\text { independence, } \\
\text { be there for } \\
\text { children }\end{array}$ \\
\hline 14. Cisty & Personalized baby products & 10 and 13 & $\mathrm{~S}$ & $\begin{array}{l}\text { Stay at } \\
\text { home } \\
\text { mother }\end{array}$ & 0 & $\mathrm{Y}$ & $\mathrm{C} / \mathrm{F}$ & 1 & $\mathrm{Y}$ & L\&E & $\begin{array}{l}\text { To be there } \\
\text { for children, } \\
\text { flexibility }\end{array}$ \\
\hline 15. Shen & Baby organic food & $\begin{array}{l}19 \text { mths, } 9 \\
\text { and } 10 \\
\text { years }\end{array}$ & M & $\begin{array}{l}\text { Stay at } \\
\text { home } \\
\text { mother }\end{array}$ & 1 & $\mathrm{~N}$ & & 4 & $\mathrm{Y}$ & Social,L\&E & $\begin{array}{l}\text { Need based } \\
\text { product }\end{array}$ \\
\hline 16. Tera & Business support services & 6 years & $\mathrm{M}$ & P.E & 2 & $\mathrm{Y}$ & $\mathrm{C} / \mathrm{F}$ & 3 & $\mathrm{~N}$ & L\&E & $\begin{array}{l}\text { To be there } \\
\text { for children, } \\
\text { dislike P.E }\end{array}$ \\
\hline 17. Alan & Game events business & 10 and 15 & $\mathrm{~S}$ & $\begin{array}{l}\text { Stay at } \\
\text { home } \\
\text { mother }\end{array}$ & 0 & $\mathrm{Y}$ & $\mathrm{C} / \mathrm{F}$ & 3 & $\mathrm{Y}$ & L\&E & $\begin{array}{l}\text { Need to be } \\
\text { independent, } \\
\text { be there for } \\
\text { children }\end{array}$ \\
\hline
\end{tabular}




\section{Summary of Table 1: Profile of Participants}

\section{Key:}

* Staff including themselves

$\mathrm{M}=$ Married and living with partner; $\mathrm{D}=$ Divorced; $\mathrm{R}=$ Remarried and living with partner; $\mathrm{S}=$ Unmarried Single Mother; $\mathrm{N}=\mathrm{No}$; $\mathrm{Y}=\mathrm{Yes}$

P.E= PAID EMPLOYMENT (working in a company)

$\mathrm{C} / \mathrm{F}=$ To be with the child/children; $\mathrm{F}=$ Flexibility in working

$\mathrm{C} / \mathrm{F} / \mathrm{I}=\mathrm{To}$ be with the child/children; $\mathrm{F}=$ Flexibility in working; $\mathrm{I}=$ least amount of investment required for a home-based business

Social,L\&E= Social Entrepreneur\& Learning and Earning Entrepreneur; Conv Ent= Convenience Entrepreneur; L\&E= Learning and Earning Entrepreneur 
